\title{
Article \\ Enhanced Nitrogen Removal from Domestic Wastewater by Partial-Denitrification/Anammox in an Anoxic/Oxic Biofilm Reactor
}

\author{
Yu Huang ${ }^{1,2}$, Yongzhen Peng ${ }^{1}$, Donghui Huang ${ }^{2}$, Jiarui Fan ${ }^{1}$ and Rui Du ${ }^{1, *}$ \\ 1 National Engineering Laboratory for Advanced Municipal Wastewater Treatment and Reuse Technology, \\ Faculty of Environment and Life, Beijing University of Technology, Beijing 100124, China; \\ hy18862145739@163.com (Y.H.); pyz@bjut.edu.cn (Y.P.); jiaruifan666@163.com (J.F.) \\ 2 Jiangsu Yulong Environment Protection Co. Ltd., NO.6 Huahui Load, Environmental Protection Industrial \\ Park, Gaocheng Town, Yixing 214214, China; rfyzhijia@163.com \\ * Correspondence: durui@bjut.edu.cn
}

Citation: Huang, Y.; Peng, Y.; Huang, D.; Fan, J.; Du, R. Enhanced Nitrogen Removal from Domestic Wastewater by Partial-Denitrification/Anammox in an Anoxic/Oxic Biofilm Reactor. Processes 2022, 10, 109. https:// doi.org/10.3390/pr10010109

Academic Editors: Albert Magrí and Tommaso Lotti

Received: 23 November 2021

Accepted: 28 December 2021

Published: 6 January 2022

Publisher's Note: MDPI stays neutral with regard to jurisdictional claims in published maps and institutional affiliations.

Copyright: (C) 2022 by the authors. Licensee MDPI, Basel, Switzerland. This article is an open access article distributed under the terms and conditions of the Creative Commons Attribution (CC BY) license (https:// creativecommons.org/licenses/by/ $4.0 /)$

\begin{abstract}
A partial-denitrification coupling with anaerobic ammonium oxidation (anammox) process $(\mathrm{PD} / \mathrm{A})$ in a continuous-flow anoxic/oxic (A/O) biofilm reactor was developed to treat carbonlimited domestic wastewater (ammonia $\left(\mathrm{NH}_{4}{ }^{+}-\mathrm{N}\right.$ ) of $55 \mathrm{mg} / \mathrm{L}$ and chemical oxygen demand (COD) of $148 \mathrm{mg} / \mathrm{L}$ in average) for about 200 days operation. Satisfactory $\mathrm{NH}_{4}{ }^{+}-\mathrm{N}$ oxidation efficiency above $95 \%$ was achieved with rapid biofilm formation in the aerobic zone. Notably, nitrite $\left(\mathrm{NO}_{2}{ }^{-} \mathrm{N}\right)$ accumulation was observed in the anoxic zone, mainly due to the insufficient electron donor for complete nitrate $\left(\mathrm{NO}_{3}{ }^{-}-\mathrm{N}\right)$ reduction. The nitrate-to-nitrite transformation ratio (NTR) achieved was as high as $64.4 \%$. After the inoculation of anammox-enriched sludge to anoxic zones, total nitrogen (TN) removal was significantly improved from $37.3 \%$ to $78.0 \%$. Anammox bacteria were effectively retained in anoxic biofilm utilizing $\mathrm{NO}_{2}{ }^{-}-\mathrm{N}$ produced via the $\mathrm{PD}$ approach and $\mathrm{NH}_{4}{ }^{+}-\mathrm{N}$ in domestic wastewater, with the relative abundance of $5.83 \%$ for stable operation. Anammox pathway contributed to TN removal by a high level of $38 \%$. Overall, this study provided a promising method for mainstream nitrogen removal with low energy consumption and organic carbon demand.
\end{abstract}

Keywords: partial-denitrification/anammox (PD/A); anoxic/oxic (A/O) biofilm reactor; nitrite accumulation; domestic wastewater; nitrogen removal

\section{Introduction}

Nitrogen discharge to water bodies can cause eutrophication and brings serious threats to human health. Nitrogen removal is the major purpose in current wastewater treatment plants (WWTPs). Nitrification/denitrification are commonly employed as traditional biological nitrogen removal technologies in WWTPs. In the first step, ammonia $\left(\mathrm{NH}_{4}{ }^{+}-\mathrm{N}\right)$ can be oxidized to nitrite $\left(\mathrm{NO}_{2}{ }^{-}-\mathrm{N}\right)$ by ammonia-oxidizing bacteria (AOB), and to nitrate $\left(\mathrm{NO}_{3}{ }^{-}-\mathrm{N}\right)$ by nitrite-oxidizing bacteria $(\mathrm{NOB})$ in the second step [1,2]. Finally, $\mathrm{NO}_{3}{ }^{-}-\mathrm{N}$ is converted to nitrogen gas $\left(\mathrm{N}_{2}\right)$ by denitrification bacteria with organic carbon as the electron donor. However, this requires a carbon source and considerable consumption of oxygen, especially for meeting stricter standards [3].

The discovery of the anaerobic ammonium oxidation (anammox) process brought new insight into a promising alternative for nitrogen removal from wastewater. In the anammox reaction, $\mathrm{NH}_{4}{ }^{+}-\mathrm{N}$ and $\mathrm{NO}_{2}{ }^{-}-\mathrm{N}$ can be converted into $\mathrm{N}_{2}$ immediately under anoxic conditions [4]. Generally, partial nitrification of $\mathrm{NH}_{4}{ }^{+}-\mathrm{N}$ oxidation to $\mathrm{NO}_{2}{ }^{-}-\mathrm{N}$ is needed to provide substrate for anammox bacteria. The combined process of partial nitrification and anammox has been successfully applied in high-strength wastewater treatment [5]. However, as for low-strength domestic wastewater, there are still challenges for engineering applications. Although increasing studies regarding the partial nitrificationanammox process in mainstream treatment have been carried out in recent years [6], 
the stability of partial nitrification is the major challenge during long-term operation. Suppression on the activity of NOB needs more effort under the conditions of low nitrogen concentration, low temperature, and fluctuated influent quality [7].

Partial denitrification (PD) has been proposed as a new approach for producing $\mathrm{NO}_{2}{ }^{-}-\mathrm{N}$ for anammox bacteria [8]. A previous study reported that high $\mathrm{NO}_{2}{ }^{-}-\mathrm{N}$ accumulation could be achieved by seeding the fermentation and denitrification sludge [9]. The nitrate-to-nitrite transformation ratio (NTR) achieved a high level of $80 \%$ during long-term operation, demonstrating the feasibility of PD for providing $\mathrm{NO}_{2}{ }^{-}-\mathrm{N}$ for anammox $[10,11]$. Compared to the traditional anammox-based process, integration with the PD process offers great advantages of low oxygen demands, reduced organic carbon consumption, and less sludge production [12]. Furthermore, nitrous oxide $\left(\mathrm{N}_{2} \mathrm{O}\right)$ production was significantly reduced under mainstream conditions according to previous study [13]. There is sufficient $\mathrm{NH}_{4}{ }^{+}-\mathrm{N}$ in domestic wastewater, which would facilitate the anammox bacteria in mainstream conditions by combining with the PD process [14]. However, the sludge retention time of anammox bacteria is relatively long owing to their low growth rate [15]. Therefore, it is vital to maintain sufficient biomass and achieve desirable bacteria retention in the reactor treating actual domestic wastewater. Biofilms have been widely regarded as an efficient tool for the retention and enrichment of anammox bacteria $[16,17]$. As for the mainstream treatment, the moving bed biofilm reactor (MBBR) has been extensively applied for the upgrade of nutrient removal processes [18,19].

Although the MBBR reactor has been widely used in WWTPs since the end of the 1980s [20], more information is needed for the engineering application of anammox-related process in terms of the start-up, optimization, and control strategies. The biofilm method can not only improve the effluent quality since less biomass was present in the discharge water than that of the suspended activated sludge process [21,22], but it can also be operated with a short hydraulic retention time (HRT) [23]. The microbial aggregation in biofilm was closely related to the extracellular polymeric substances and secretory extracellular organic matter [24]. Typically, anammox bacteria have been reported to occur as an attached growth, and the interfaces of contrast phases were the hotspot of anammox reaction [25]. This would benefit its competition for substrate with denitrifying bacteria in the suspended sludge [26,27]. Therefore, the biofilm process is assumed to be more suitable for practical application of the anammox-related processes, i.e., PD combining with anammox (PD/A) process [28]. To date, most studies on PD/A were conducted in sequencing batch reactors (SBR) or fixed bed reactors [13,17]. Considering the wide application of the continuousflow process, it would be necessary to investigate the performance and stability of the novel technology before its practical implementation. However, limited information was available especially for the start-up and long-term nitrogen removal performance when treating actual domestic wastewater.

Therefore, the current study aims to develop a PD/A followed by nitrification biofilms in a continuous-flow anoxic/oxic (A/O) system with carriers added in both aerobic and anoxic zones. This holds the advantage of efficient retention of slow-growth nitrifying bacteria in the aerobic zone and anammox bacteria in the anoxic zone, which differs from previous studies that applied the PD/A process in mainstream treatment [29]. Actual domestic wastewater with low $\mathrm{C} / \mathrm{N}$ was used as influent during the whole experiment. The performance of $\mathrm{PD}$ in the anoxic zone without anammox was investigated during longterm operation. The PD/A process was then established and the enrichment of functional bacteria in biofilm was evaluated. Results are expected to provide new insight into the design, operation, and optimization of anammox-related mainstream treatment.

\section{Materials and Methods}

\subsection{Reactor and Operation}

The continuous-flow A/O biofilm reactor was made of transparent plexiglas, which was divided into nine compartments (Figure 1). The first four compartments were set as anoxic zones, while the latter four were aerobic zones, resulting in the volume ratio of the 
anoxic to the aerobic zone of 1:1. The last zone was an effluent discharging compartment. Each compartment possessed a working volume of $3 \mathrm{~L}$, resulting in the total working volume of the whole reactor of $24 \mathrm{~L}$. In each compartment, 100 polyethylene carriers were added with a filling ratio of around $33 \%$. The carriers in the four anoxic zones were fixed by string and the diving mixer was installed in each compartment to guarantee the complete mixture. The carriers used in this study were made of polyethylene with a specific surface area of $500 \mathrm{~m}^{2} / \mathrm{m}^{3}$. In aerobic zones, aeration was implemented by using an air pump to supply a porous stone diffuser at the bottom of the reactor. The dissolved oxygen (DO) was in range of $1.5 \sim 2.0 \mathrm{mg} / \mathrm{L}$. Influent and effluent recycling were controlled using a peristaltic pump.

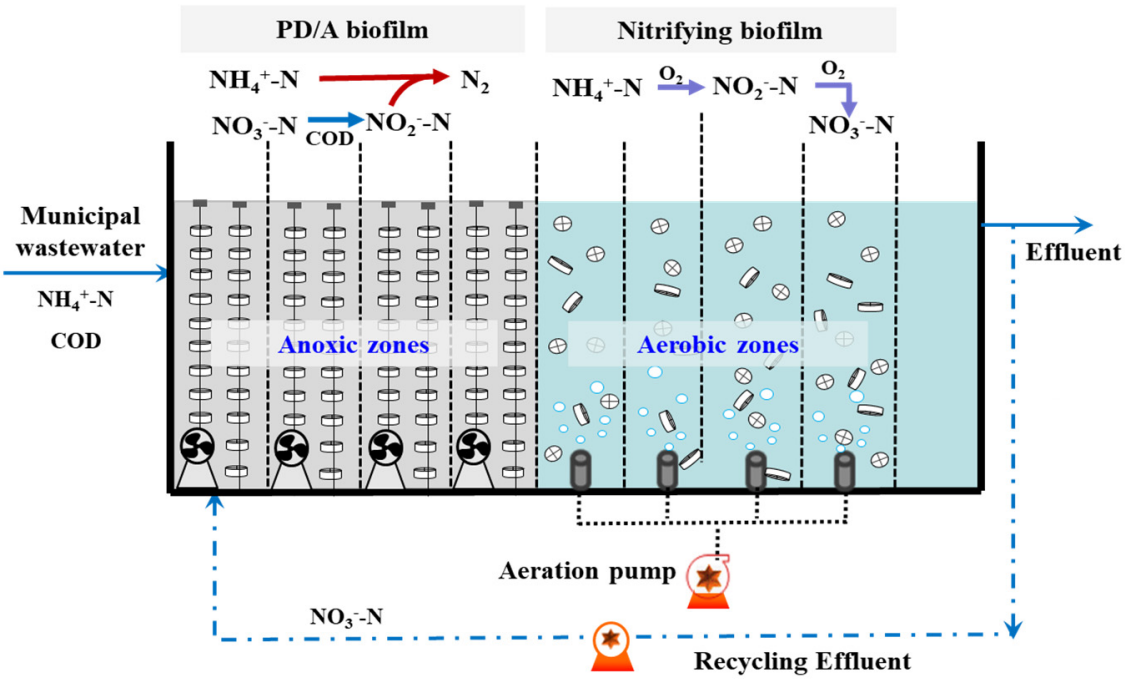

Figure 1. Schematic diagram of the $\mathrm{PD} / \mathrm{A}$ anoxic/oxic biofilm reactor.

The seeding sludge was taken from a laboratory-scale endogenous post-denitrification and phosphorus removal system treating actual domestic wastewater [30]. The domestic wastewater was collected from a residential area of Beijing University of Technology (Beijing, China). The detailed characteristics of domestic wastewater are presented in Table 1. The influent flow rate was constant at $2 \mathrm{~L} / \mathrm{h}$, resulting in a total HRT of $12 \mathrm{~h}$. During the operation process, the effluent recycling ratio was maintained at $200 \%$. The reactor was operated at room temperature, which varied with seasonal change. The whole operation process could be divided into three phases as follows.

Table 1. The influent characteristics of domestic wastewater.

\begin{tabular}{|c|c|c|c|c|c|c|}
\hline Concentration & COD (mg/L) & $\mathrm{NH}_{4}{ }^{+}-\mathrm{N}(\mathrm{mg} / \mathrm{L})$ & $\mathrm{NO}_{3}{ }^{-}-\mathrm{N}(\mathrm{mg} / \mathrm{L})$ & TN (mg/L) & $\mathrm{C} / \mathrm{N}$ & Temperature $\left({ }^{\circ} \mathrm{C}\right)$ \\
\hline Range & $99-250$ & $41-80$ & $0-1.1$ & $41-81$ & $1.5-4.9$ & $13.5-29.4$ \\
\hline Mean value & $148 \pm 37$ & $55 \pm 9.0$ & $0.4 \pm 0.3$ & $56 \pm 9.1$ & $2.68 \pm 0.7$ & 21.8 \\
\hline
\end{tabular}

Phase I: Biofilm formation (day 1-58). New carriers were added into both the anoxic and aerobic zone. It was expected that the heterotrophic denitrifying organisms and nitrifying bacteria could be enriched by biofilm formation [31]. The recycling effluent contained $\mathrm{NO}_{3}{ }^{-}-\mathrm{N}$ and the carbon source in raw water could provide favorable conditions for denitrifying bacteria in anoxic zones.

Phase II: $\mathrm{NO}_{2}{ }^{-} \mathrm{N}$ accumulation during denitrification (day 59-106). With the denitrifying bacteria growth attached to the anoxic biofilm and in suspended sludge, $\mathrm{NO}_{2}{ }^{-} \mathrm{N}$ accumulation occurred, which was also observed in a previous study on partial denitrification [32]. Biofilms were relatively thin at this stage [33].

Phase III: Addition of anammox sludge (day 107-199). The anammox sludge was collected from a pilot-scale reactor treating anaerobic digestion filtrate and was inoculated 
to the anoxic zones [34]. A filter screen was added to the outlet of the latter two anoxic compartments of anoxic zones. The nitrogen removal performance and the stability of $\mathrm{PD} / \mathrm{A}$ and the nitrification biofilm system were evaluated in this stage.

\subsection{Batch Tests for $\mathrm{NO}_{3}{ }^{-}-\mathrm{N}$ Reduction and $\mathrm{NO}_{2}{ }^{-}-\mathrm{N}$ Accumulation Capacity of Anoxic Biofilms}

The $\mathrm{NO}_{3}{ }^{-}-\mathrm{N}$ reduction and $\mathrm{NO}_{2}{ }^{-}-\mathrm{N}$ accumulation capacity of denitrification in anoxic biomass was evaluated on day 102. The carriers in the anoxic zones were taken out and transferred to four SBR with a working volume of $1.0 \mathrm{~L}$. The feeding wastewater used in batch tests was similar to the influent of the reactor, which was mixed with the domestic wastewater and effluent of the $\mathrm{A} / \mathrm{O}$ reactor using a volume ratio of 1:2. Subsequently, 33 carriers were removed from each anoxic compartment in the reactors. Nitrogen gas was purged into the reactors for $10 \mathrm{~min}$ to drive out $\mathrm{DO}$ before the reaction. The reaction lasted for $6 \mathrm{~h}$ during each test. A total of eleven samples were taken for nitrogen concentration measurement, including the first four samples taken in the first hour, another four samples taken in the next two hours, and the last three samples taken in the last three hours. The $\mathrm{pH}$ was maintained at 7.0-7.5 during the test by adding $\mathrm{HCl}$ or $\mathrm{NaOH}$ solution. The batch tests were repeated three times.

\subsection{Ex-situ Activity of Denitrification Coupling with Anammox}

Ex-situ activity of denitrification coupled with anammox was investigated on day 180 and the tests were conducted three times. Specifically, 33 carriers were removed from each of the four anoxic compartments and transferred to the SBRs. The feeding water was prepared by mixing actual domestic wastewater and effluent of the reactor at a volume ratio of 1:2. Nitrogen gas was purged into the reactors for $10 \mathrm{~min}$ to drive out DO before the reaction. The $\mathrm{pH}$ was maintained at 7.0-7.5 during the test by adding $\mathrm{HCl}$ or $\mathrm{NaOH}$ solution. The ex situ activities of denitrification coupling anammox were determined by the $\mathrm{NO}_{2}{ }^{-}-\mathrm{N}$ reduction rates and $\mathrm{NH}_{4}{ }^{+}-\mathrm{N}$ removal rates during the reaction.

\subsection{Oxygen Uptake Rate (OUR) of $A O B, N O B$, and Ordinary Heterotrophic Organisms (OHO)}

Batch tests were conducted to evaluate the $\mathrm{NH}_{4}{ }^{+}-\mathrm{N}$ removal pathway in anoxic biofilm on day 192. Aerobic OUR was measured to detect the possible nitrification activity of AOB, $\mathrm{NOB}$, and oxygen consumption by $\mathrm{OHO}$ using a respirometer (Strathtox, Strathkelvin, England). Taking into consideration that DO was very limited in the third and fourth anoxic, the aerobic $\mathrm{NH}_{4}{ }^{+}-\mathrm{N}$ removal capacity could be negligible. Therefore, ten carriers were taken from the first two compartments in anoxic zones for the OUR measurement. The samples were washed three times to remove the residual substrate and the biomass attached to the carriers was scraped off and equally added into three flasks with a working volume of $500 \mathrm{~mL}$. The four groups of batch tests consisted of the control group without biomass and three tests for the OUR of $\mathrm{AOB}, \mathrm{NOB}$, and $\mathrm{OHO}$. DO probes were connected to the flasks for real-time recording of DO concentration. The batch tests were conducted three times.

\subsection{Analytical Methods}

All samples were collected using $0.45 \mu \mathrm{m}$ filter paper before analysis. $\mathrm{NH}_{4}{ }^{+}-\mathrm{N}$, $\mathrm{NO}_{2}{ }^{-}-\mathrm{N}$, and $\mathrm{NO}_{3}{ }^{-}-\mathrm{N}$ were analyzed using the Lachat Quik-Chem8000 Flow Injection Analyzer (Lachat Instrument, Milwaukee, WI, USA). Chemical oxygen demand (COD) was analyzed using the COD quick-analysis apparatus (Lian-Hua Tech. Co., Ltd., Beijing, China). Mixed liquor suspended solids (MLSS) and mixed liquor volatile suspended solid (MLVSS) were analyzed by standard methods [35]. Moreover, temperature, $\mathrm{pH}$, and DO were measured using a detector of Multi 3420 meter (WTW Company, Munich, Germany).

\subsection{Real-Time Quantitative Polymerase Chain Reaction ( $q P C R$ )}

The abundances of AOB, Nitrospira, Nitrobacter, anammox bacteria, and total bacteria were determined by real-time qPCR using an MX3000P Real-Time PCR system 
(Stratagene, La Jolla, CA, USA) with fluorescent SYBR-Green. In addition, the genomic DNA of the sludge sample was extracted using the Fast DNA SPIN kits for soil (Bio 101, Vista, CA, USA). All assays were performed in $20 \mu \mathrm{L}$ reaction mixtures consisting of $10 \mu \mathrm{L}$ SYBR Green exTaq (Takara, Dalian, China), $7 \mu \mathrm{L}$ deionized water, $0.4 \mu \mathrm{L}$ ROX Reference Dye $50,0.3 \mu \mathrm{L}$ of each primer $(10 \mathrm{mmol} / \mathrm{L})$, and $2 \mu \mathrm{L}$ DNA template (1-10 $\mathrm{ng})$. To be specific, such a process consisted of the following steps: $3 \mathrm{~min}$ at $95^{\circ} \mathrm{C}$, followed by 40 cycles of the $30 \mathrm{~s}$ at $95{ }^{\circ} \mathrm{C}, 30 \mathrm{~s}$ at corresponding annealing temperature, and $45 \mathrm{~s}$ at $72{ }^{\circ} \mathrm{C}$. Notably, the corresponding annealing temperatures are listed in Table 2 . The qPCR was repeated three times for each group of bacteria.

Table 2. The primers and the annealing temperature.

\begin{tabular}{cccccc}
\hline Specificity & $\begin{array}{c}\text { AOB } \\
\text { amo A }\end{array}$ & $\begin{array}{c}\text { Nitrospira } \\
\text { 16S rRNA }\end{array}$ & $\begin{array}{c}\text { Nitrobacter } \\
\text { 16S rRNA }\end{array}$ & $\begin{array}{c}\text { Anammox bacteria } \\
\text { 16S rRNA }\end{array}$ & $\begin{array}{c}\text { Total bacteria } \\
\text { 16S rRNA }\end{array}$ \\
\hline $\begin{array}{c}\text { Former Primer } \\
\text { Reverse Primer }\end{array}$ & $\begin{array}{c}\text { amoA-1F } \\
\text { amoA-2R }\end{array}$ & $\begin{array}{c}338 \mathrm{~F} \\
685 \mathrm{R}\end{array}$ & $\begin{array}{c}\text { FGPS872F } \\
\text { FGPS1269R }\end{array}$ & Amx368F & Amx820R \\
\hline $\begin{array}{c}\text { Annealing } \\
\text { temperature }\left({ }^{\circ} \mathrm{C}\right)\end{array}$ & 55 & 53 & 51 & 56 & $534 \mathrm{~F}$ \\
\hline
\end{tabular}

\subsection{Calculations}

The $\mathrm{NO}_{3}{ }^{-}-\mathrm{N}-$ to- $\mathrm{NO}_{2}{ }^{-}-\mathrm{N}$ transformation ratio in the anoxic zone ( $\mathrm{NTR}_{\mathrm{an}}$ ) was calculated according to Equation (1):

$$
\mathrm{NTR}_{\mathrm{an}}=\left(\text { Terminal } \mathrm{NO}_{2}^{-}-\mathrm{N}_{\mathrm{an}}-\text { Initial } \mathrm{NO}_{2}^{-}-\mathrm{N}_{\mathrm{an}}\right) \times 100 /\left(\text { Initial } \mathrm{NO}_{3}^{-}-\mathrm{N}_{\mathrm{an}}-\text { Terminal } \mathrm{NO}_{3}^{-}-\mathrm{N}_{\mathrm{an}}\right)
$$

where Terminal $\mathrm{NO}_{2}{ }^{-}-\mathrm{N}_{\mathrm{an}}$ and Initial $\mathrm{NO}_{2}{ }^{-}-\mathrm{N}_{\text {an }}$ represent the $\mathrm{NO}_{2}{ }^{-}-\mathrm{N}$ concentration at the end and beginning of the entire anoxic zone, respectively; similarly, Terminal $\mathrm{NO}_{3}{ }^{-}-\mathrm{N}_{\mathrm{an}}$ and Initial $\mathrm{NO}_{3}{ }^{-}-\mathrm{N}_{\text {an }}$ represent the $\mathrm{NO}_{3}{ }^{-}-\mathrm{N}$ concentration at the end and beginning of the entire anoxic zone, respectively.

The contribution of anammox pathway to $\mathrm{TN}$ removal was calculated by Equations (2)-(4) [17]:

$$
\begin{gathered}
\text { Contribution of anammox }=\left(\Delta \mathrm{NH}_{4}^{+}-\mathrm{N}+1.32 \Delta \mathrm{NH}_{4}^{+}-\mathrm{N}-0.26 \Delta \mathrm{NH}_{4}^{+}-\mathrm{N}\right) \times 100 \% / \mathrm{TN} \text { removal } \\
\qquad \mathrm{NH}_{4}^{+}-\mathrm{N}=\text { Theoretical } \mathrm{NH}_{4}^{+}-\mathrm{N}_{\mathrm{an}}-\text { Measured } \mathrm{NH}_{4}^{+}-\mathrm{N}_{\mathrm{an}} \\
\mathrm{TN} \text { removal }=\mathrm{TN}_{\text {effluent }}-\mathrm{TN}_{\text {influent }}
\end{gathered}
$$

where $\triangle \mathrm{NH}_{4}{ }^{+}-\mathrm{N}$ refer to the $\mathrm{NH}_{4}{ }^{+}-\mathrm{N}$ loss in anoxic zones, determined by theoretical concentration (Theoretical $\mathrm{NH}_{4}{ }^{+}-\mathrm{N}_{\mathrm{an}}$ ) and measured concentration of $\mathrm{NH}_{4}{ }^{+}-\mathrm{N}$ (Measured $\mathrm{NH}_{4}{ }^{+}-\mathrm{N}_{\text {an }}$ ) at the end of anoxic zones; specially, theoretical $\mathrm{NH}_{4}{ }^{+}-\mathrm{N}_{\text {an }}$ was calculated according to the influent $\mathrm{NH}_{4}{ }^{+}-\mathrm{N}$ of the domestic wastewater by applying the recycling rate in this study. TN removal was determined by influent and effluent TN concentration in the system.

\section{Results and Discussion}

\subsection{Performance of A/O Biofilm System for Domestic Wastewater Treatment \\ 3.1.1. Start-Up and Biofilm Formation}

The long-term performance of $\mathrm{A} / \mathrm{O}$ biofilm with carriers in both anoxic and the following aerobic zones was evaluated. The entire operation could be divided into three phases and the conditions are summarized in Table 1. The nitrogen and COD removal were tracked during the 199 day operation (Figure 2). It showed that the effluent $\mathrm{NH}_{4}{ }^{+}-\mathrm{N}$ was at a high level in the initial operation, indicating insufficient nitrification performance (Figure 2a). It decreased gradually with the acclimatization of bacteria. After 50 days of operation, the $\mathrm{NH}_{4}{ }^{+}-\mathrm{N}$ oxidization efficiency increased from below $1 \%$ to over $95 \%$ with the effluent $\mathrm{NH}_{4}{ }^{+}-\mathrm{N}$ below $5 \mathrm{mg} / \mathrm{L}$. This was maintained stably during the following operation, indicating the complete recovery of nitrification activity. 

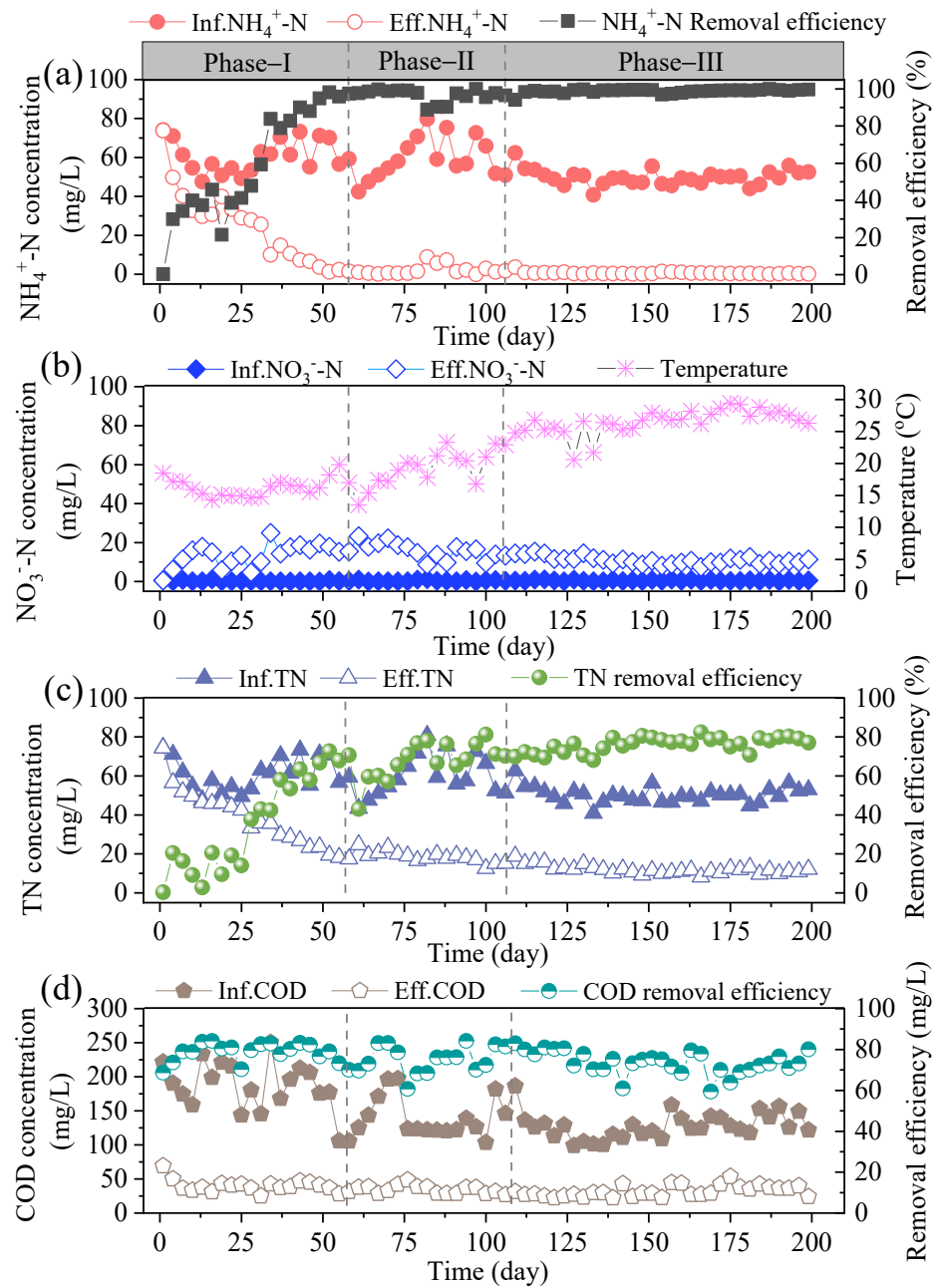

Figure 2. Long-term performance of nitrogen and COD removal in a continuous-flow A/O biofilm system: (a) influent and effluent $\mathrm{NH}_{4}{ }^{+}-\mathrm{N}$ concentration and removal efficiency; (b) $\mathrm{NO}_{3}{ }^{-}-\mathrm{N}$ concentration and temperature; (c) influent and effluent TN concentration and removal efficiency; (d) influent and effluent TN concentration and removal efficiency.

Moreover, the formation of biofilm in the aerobic zone was observed after 59 days of operation, which was assumed to benefit the attached growth and retention of the nitrifying bacteria. This was supported by a previous study showing that the biofilm played a major role in nitrification, as it predominated over the suspended solids at higher media filling fractions [36]. Notably, the nitrifying bacteria (AOB and NOB) were chemoautotrophic and required no organic substances. Specifically, the heterotrophic bacteria would become the dominant bacteria using the organic substances in raw wastewater. This would possibly lead to competition between heterotrophic bacteria and nitrifying bacteria for DO and other nutrients. In this study, although the domestic wastewater was used as the influent containing a certain amount of organic matter, it would have little negative effect on the rapid recovery of nitrification and biofilm formation. This was mainly due to the consumption of COD in the former anoxic zone.

In comparison, more rapid recovery of COD removal was obtained, which was demonstrated by the increasing COD removal efficiency from $68.7 \%$ to $79.1 \%$ after 7 days of operation (Figure 2d). The effluent COD concentration was maintained below $50 \mathrm{mg} / \mathrm{L}$ during this phase. This suggested that the heterotrophic bacteria could be recovered more quickly than nitrifying bacteria. Therefore, nitrification became the limited step in the startup of the biofilm system treating actual domestic wastewater. However, it could be seen that the relatively high effluent $\mathrm{TN}$, greater than $20 \mathrm{mg} / \mathrm{L}$, was eventually discharged due 
to the high $\mathrm{NH}_{4}{ }^{+}-\mathrm{N}$ residual (Figure 2c). With the recovery of nitrification activity, effluent $\mathrm{NH}_{4}{ }^{+}-\mathrm{N}$ decreased gradually while the $\mathrm{TN}$ remained above $15 \mathrm{mg} / \mathrm{L}$ in phase I. There was up to $19 \mathrm{mg} / \mathrm{L} \mathrm{NO}_{3}{ }^{-}-\mathrm{N}$ residual in the effluent, indicating insufficient denitrification performance due to the limited organic carbon in raw wastewater (Table 3).

Table 3. Performance of A/O biofilm system during three operation phases.

\begin{tabular}{|c|c|c|c|c|c|c|c|c|}
\hline \multirow{2}{*}{ Phase } & \multirow{2}{*}{ Time (day) } & \multicolumn{3}{|c|}{ Influent Concentration (mg/L) } & \multicolumn{4}{|c|}{ Effluent Concentration (mg/L) } \\
\hline & & $\mathrm{NH}_{4}^{+}-\mathrm{N}$ & $\mathrm{NO}_{3}{ }^{-}-\mathrm{N}$ & COD & $\mathrm{NH}_{4}^{+}-\mathrm{N}$ & $\mathrm{NO}_{2}{ }^{-}-\mathrm{N}$ & $\mathrm{NO}_{3}{ }^{-}-\mathrm{N}$ & COD \\
\hline I & $1-58$ & $61 \pm 8.4$ & $0.25 \pm 0.30$ & $184 \pm 39$ & $24 \pm 19$ & $0.44 \pm 0.25$ & $13 \pm 5.8$ & $40 \pm 9.3$ \\
\hline II & 59-106 & $60 \pm 11$ & $0.41 \pm 0.39$ & $141 \pm 29$ & $2.3 \pm 2.7$ & $0.41 \pm 0.27$ & $16 \pm 4.3$ & $35 \pm 6.1$ \\
\hline III & 107-199 & $50 \pm 4.1$ & $0.48 \pm 0.30$ & $128 \pm 19$ & $0.64 \pm 0.6$ & $0.38 \pm 0.24$ & $11 \pm 2.0$ & $32 \pm 8.2$ \\
\hline
\end{tabular}

After 58 days, it was considered that the reactor was successfully started since the $\mathrm{NH}_{4}{ }^{+}-\mathrm{N}$ removal efficiency was achieved above $90 \%$ and maintained for 5 days, with the bacterial growth observed on the carriers. It was assumed that the nitrifying bacteria could grow attached to the carriers but with a low abundance due to its slow growth rate. Although the denitrifying bacteria exhibit much higher growth rates than the autotrophic bacteria, efficient retention of nitrifying bacteria was speculated to be achieved and attributed to the biofilm formation. The ammonium transport was reported to be related to the substrate concentration, and the oligotrophic environments would result in a decrease in cell growth of $\mathrm{AOB}$, since more cellular energy was consumed in ammonia loss and recovery [2]. In this case, growth on the biofilm would provide a more suitable environment for AOB to mass transfer between cells. However, further improvement of the nitrogen removal performance needs to be considered.

\subsection{2. $\mathrm{NO}_{2}{ }^{-}-\mathrm{N}$ Accumulation in Anoxic Zone}

To investigate the development and efficiency of partial denitrification in the continuousflow biofilm system, $\mathrm{NO}_{2}{ }^{-}-\mathrm{N}$ and $\mathrm{NH}_{4}{ }^{+}-\mathrm{N}$ concentrations in the anoxic zone were measured, as shown in Figure 3. It should be noted that the obvious accumulation of $\mathrm{NO}_{2}{ }^{-}-\mathrm{N}$ occurred in the anoxic zones after 67 days of stable operation, with the $\mathrm{NO}_{2}{ }^{-}-\mathrm{N}_{\text {an }}$ concentration in anoxic effluent of $1.1 \mathrm{mg} / \mathrm{L}$ (Figure 3a). Subsequently, consecutive $\mathrm{NO}_{2}{ }^{-} \mathrm{N}$ accumulation was identified and slightly increased in the anoxic zones, which peaked at 106 days with $6.0 \mathrm{mg} / \mathrm{L}$ and $\mathrm{NTR}_{\mathrm{an}}$ of $64 \%$. According to the best of our knowledge, this was at a relatively high level of $\mathrm{NO}_{2}{ }^{-}-\mathrm{N}$ accumulation in the continuous plug-flow reactor. A previous study also reported a similar phenomenon of $\mathrm{NO}_{2}{ }^{-}-\mathrm{N}$ accumulation in the anoxic zone of a modified UCT (University of Cape Town) step-feed reactor treating municipal wastewater, with the greatest value of about $2.5 \mathrm{mg} / \mathrm{L}$ [37]. The level $\mathrm{NO}_{2}{ }^{-}-\mathrm{N}$ accumulation in this study was higher than that in the previous study, and it was detected from the first anoxic compartment to the end of the anoxic compartment during phase II. This mainly resulted from insufficient electron donor in the domestic wastewater for complete $\mathrm{NO}_{3}{ }^{-}-\mathrm{N}$ reduction. Meanwhile, the effluent concentration of $\mathrm{NO}_{3}{ }^{-}-\mathrm{N}$ decreased. This most likely occurred because the electron donor for reducing $\mathrm{NO}_{3}{ }^{-}-\mathrm{N}$ was saved due to the $\mathrm{NO}_{2}{ }^{-}-\mathrm{N}$ accumulation; more organic carbon source could be used to reduce $\mathrm{NO}_{3}{ }^{-}-\mathrm{N}$, resulting in the lower effluent $\mathrm{NO}_{3}{ }^{-}-\mathrm{N}$.

According to previous studies, high $\mathrm{NO}_{2}{ }^{-}-\mathrm{N}$ accumulation could be achieved in a sequencing batch reactor with the NTR above 70\% [38], while the stable $\mathrm{NO}_{2}{ }^{-}-\mathrm{N}^{-}$accumulation in the anoxic zone at this high level in a continuous-flow biofilm reactor for actual municipal wastewater treatment has been rarely reported. In this study, the $\mathrm{NO}_{2}{ }^{-}-\mathrm{N}$ concentration at the end of the anoxic zone increased from 0.2 to $6.0 \mathrm{mg} / \mathrm{L}$, with the initial $\mathrm{NO}_{2}{ }^{-}-\mathrm{N}$ concentration of the anoxic stage maintained at a very low level of $0.2 \mathrm{mg} / \mathrm{L}$ on average. During this phase, the $\mathrm{NTR}_{\text {an }}$ increased from $0.97 \%$ to $64.4 \%$, which was comparable to the value in previous studies with synthetic wastewater and an external carbon source [39]. Therefore, this study offered an effective approach to achieve anammox 
by providing a stable substrate in an $\mathrm{A} / \mathrm{O}$ biofilm system. Moreover, the $\mathrm{NH}_{4}{ }^{+}-\mathrm{N}$ was abundant in the domestic wastewater, and it maintained sufficient concentration at the end of anoxic, as shown in Figure 3a. It was assumed that the $\mathrm{NO}_{2}{ }^{-}-\mathrm{N}$ accumulation and $\mathrm{NH}_{4}{ }^{+}-\mathrm{N}$ residue in the anoxic zones provided favorable conditions for the growth of anammox bacteria.
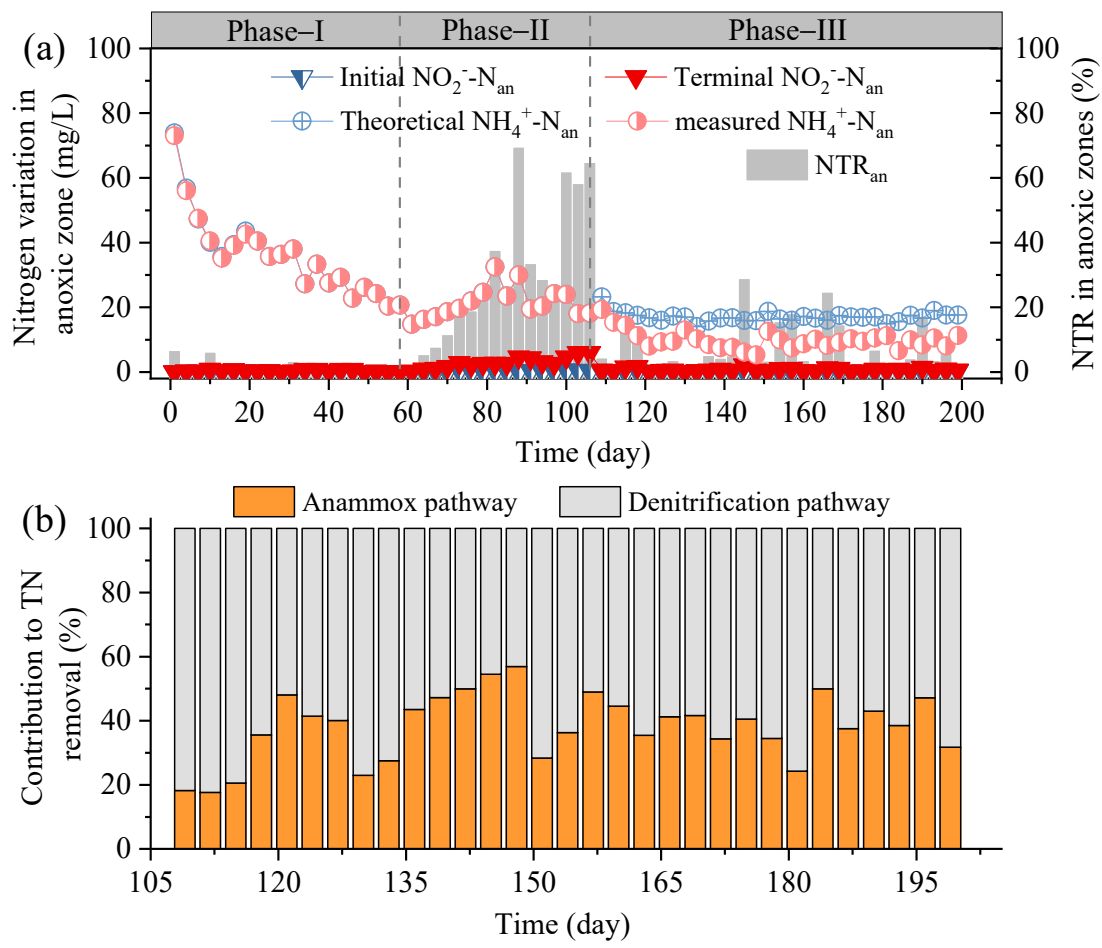

Figure 3. (a) Variation of $\mathrm{NO}_{2}{ }^{-}-\mathrm{N}$ and $\mathrm{NH}_{4}{ }^{+}-\mathrm{N}$ concentration during long-term operation of the anoxic zone of the $\mathrm{A} / \mathrm{O}$ biofilm reactor. Typically the initial and terminal $\mathrm{NO}_{2}{ }^{-}-\mathrm{N}$ concentration in the anoxic zone (initial $\mathrm{NO}_{2}{ }^{-}-\mathrm{N}_{\mathrm{an}}$, terminal $\mathrm{NO}_{2}{ }^{-}-\mathrm{N}_{\mathrm{an}}$ ) was tracked. The theoretical and measured value of $\mathrm{NH}_{4}{ }^{+}-\mathrm{N}$ concentration at the end of anoxic zone (initial $\mathrm{NH}_{4}{ }^{+}-\mathrm{N}_{\mathrm{an}}$, terminal $\mathrm{NH}_{4}{ }^{+}-\mathrm{N}_{\mathrm{an}}$ ) were analyzed, and $\mathrm{NTR}_{\mathrm{an}}$ was referred to the nitrate-to-nitrite ratio during the anoxic reaction period. (b) Contribution of anammox and denitrification pathways to TN removal of the entire system in phase III.

To evaluate the feasibility of advanced nitrogen removal by the PD/A process, the $\mathrm{NO}_{2}{ }^{-}-\mathrm{N}$ production capability of anoxic biofilm was evaluated by batch test with the biofilm taken from the four anoxic compartments.

Gradual $\mathrm{NO}_{2}{ }^{-}-\mathrm{N}$ accumulation along with $\mathrm{NO}_{3}{ }^{-}-\mathrm{N}$ reduction was observed (Figure 4). The $\mathrm{NO}_{2}{ }^{-}-\mathrm{N}$ accumulation rates were much higher during the first three hours and then decreased. The accumulated $\mathrm{NO}_{2}{ }^{-}-\mathrm{N}$ concentration achieved a steady level after four hours. The $\mathrm{NO}_{2}{ }^{-}-\mathrm{N}$ accumulation efficiency in the second anoxic zone was the highest, and the last anoxic zone showed the lowest value, corresponding to the NTR in the four anoxic zones of $63.8 \%, 71.7 \%, 68.9 \%$, and $59.3 \%$, respectively. This would be related to the higher microbial community for $\mathrm{NO}_{3}{ }^{-}-\mathrm{N}$ reduction when the water flows into anoxic- 2 after anoxic-1, which would improve the denitrification activity of the biomass in anoxic-2. Moreover, the organic carbon source decreased to the lower level in anoxic-3 and anoxic-4 compared to anoxic-2, resulting in a decreased $\mathrm{NO}_{3}{ }^{-}-\mathrm{N}$ reduction efficiency and $\mathrm{NO}_{2}{ }^{-}-\mathrm{N}$ generation. This indicated that the HRT and organic carbon source could play important roles in the development of the PD/A process. Results of this study proved that the partial denitrification with stable $\mathrm{NO}_{2}{ }^{-}-\mathrm{N}$ generation could be achieved successfully in a continuous-flow biofilm system, thus providing a meaningful method to achieve mainstream anammox in practical application. 


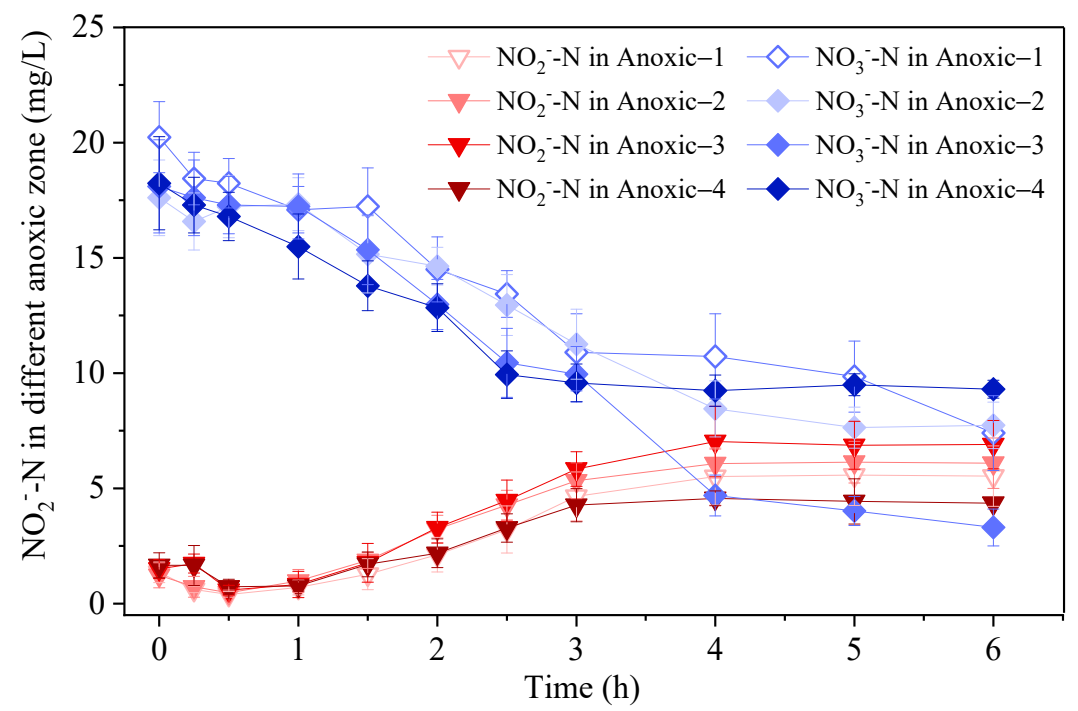

Figure 4. Evaluation of $\mathrm{NO}_{2}{ }^{-}-\mathrm{N}$ accumulation capacity during $\mathrm{NO}_{3}{ }^{-}-\mathrm{N}$ reduction of biofilms taken from the anoxic zones.

\subsection{Development of Partial Denitrification/Anammox in A/O Biofilm System}

Based on the results described above, stable and efficient $\mathrm{NO}_{2}{ }^{-}-\mathrm{N}$ accumulation in the anoxic zone was observed and assumed to provide a suitable environment for the growth of anammox bacteria. Therefore, during phase III, the anammox-enriched sludge was inoculated on day 109 to investigate the feasibility and performance of the PD/A process in this system.

Results showed that there was an obvious gradual decrease in $\mathrm{NH}_{4}{ }^{+}-\mathrm{N}$ concentration in the anoxic zones, as shown in Figure 3, which declined from 19 to $11 \mathrm{mg} / \mathrm{L}$ at the end of the anoxic stage after the addition of anammox sludge. It indicated that the anammox activity occurred by consuming $\mathrm{NH}_{4}{ }^{+}-\mathrm{N}$ and $\mathrm{NO}_{2}{ }^{-}-\mathrm{N}$ under this condition. This was also illustrated by the decrease of $\mathrm{NO}_{2}{ }^{-}-\mathrm{N}$ accumulation in the anoxic zone, which declined from 6.0 to $0.5 \mathrm{mg} / \mathrm{L}$ at the end of the operation. Moreover, the effluent $\mathrm{NO}_{3}{ }^{-}-\mathrm{N}$ concentration decreased gradually in the final effluent, corresponding to the effluent TN decreasing to $11 \mathrm{mg} / \mathrm{L}$ on average during the stable operation from day 154 to 199 . The TN removal efficiency increased to $78.0 \%$ and was much higher than that in phase I $(37.3 \%$ on average). This demonstrated that the PD/A could be developed successfully in the A/O biofilm system for advanced nitrogen removal from actual domestic wastewater. It should be noted that very limited growth of biomass was found in the biofilm system. The average MLSS in anoxic zones was about $1200 \mathrm{mg} / \mathrm{L}$, which was about $700 \mathrm{mg} / \mathrm{L}$ in aerobic zones at the end of the operation. This suggested that the novel PD/A biofilm system holds great advantages in achieving substantially large nitrogen removal loading rates with reducing sludge production.

On the other hand, results in this study implied that the PD and anammox bacteria could be efficiently retained in an anoxic zone via rapid biofilm formation. A previous study also reported that the PD/A process could be achieved in a step-feed anoxic-oxic (A/O) system by adding the carriers containing anammox bacteria [40], while different results showed that the activity of anammox was lower under the carriers-only condition, compared to that under the hybrid condition of carriers and flocs. In this study, blank carriers were added into both the anoxic and aerobic zone, indicating that the rapid formation of $\mathrm{PD} / \mathrm{A}$ biofilm played a key role in enhanced nitrogen removal performance. Therefore, it provided an efficient strategy to improve the nitrogen removal performance in mainstream treatment without mature anammox biofilm and low biomass concentration. 


\subsection{Removal Pathway of $\mathrm{NH}_{4}{ }^{+}-\mathrm{N}$ in Anoxic Stage}

It should be noted that the $\mathrm{DO}$ in recycling nitrification effluent of $\mathrm{A} / \mathrm{O}$ was at a relatively high level. There might be simultaneous nitrification and denitrification responsible for $\mathrm{NH}_{4}{ }^{+}-\mathrm{N}$ removal in anoxic zones apart from the anammox process. Consequently, it was necessary to verify whether autotrophic (anammox) or heterotrophic (complete denitrification) pathways would be responsible for the $\mathrm{NH}_{4}{ }^{+}-\mathrm{N}$ loss in the anoxic zone. The maximum OUR of $\mathrm{AOB}, \mathrm{NOB}$, and $\mathrm{OHO}$ were measured with biofilm samples taken from anoxic zones for estimation of the nitrification activity. Results showed that the activity of $\mathrm{OHO}$ was far greater than those of AOB and NOB in the case of organic compounds (Figure 5). Meanwhile, $\mathrm{OHO}$ consumed oxygen at a rate of $21.23 \mathrm{mgO}_{2} /(\mathrm{gVSS} \cdot \mathrm{h})$ in the first anoxic zone, which was much higher than the $4.04 \mathrm{mgO}_{2} /(\mathrm{gVSS} \cdot \mathrm{h})$ of $\mathrm{AOB}$ and $2.41 \mathrm{mgO}_{2} /(\mathrm{gVSS} \cdot \mathrm{h})$ of NOB. In addition, $\mathrm{OHO}$ consumed oxygen at a rate of $13.39 \mathrm{mgO}_{2} /(\mathrm{gVSS} \cdot \mathrm{h})$ in the latter anoxic zones, which were $1.44 \mathrm{mgO}_{2} /\left(\mathrm{gVSS} \cdot \mathrm{h}\right.$ ) and $2.16 \mathrm{mgO}_{2} /(\mathrm{gVSS} \cdot \mathrm{h}$ ) for $\mathrm{AOB}$ and $\mathrm{NOB}$, respectively. Moreover, since there was sufficient carbon source in anoxic zones, DO was preferentially consumed by $\mathrm{OHO}$ due to the rapid reaction rates, indicating that the nitrification in anoxic zones would be very limited. It should be noted that there is a difference in aerobic respiration rates of the biomass on anoxic carriers between values in the batch tests and actual operation in the reactor due to the substrate transfer limitation in biofilm. Moreover, it was difficult to maintain the DO and substrate concentration at the same level. Therefore, more detailed evidence and thus analysis of microbial abundance was needed to confirm the contribution of the anammox pathway on nitrogen removal in anoxic zones, which is discussed in the following section. This agreed well with a previous study on the enhanced $\mathrm{NH}_{4}{ }^{+}$-N removal that occurred in a full-scale wastewater treatment plant by adding moving carriers into the anoxic zone, with the anammox contribution accounting for $15.9 \%$ due to PD providing substrate [41]. Therefore, the PD/A is a promising and feasible method for mainstream treatment.

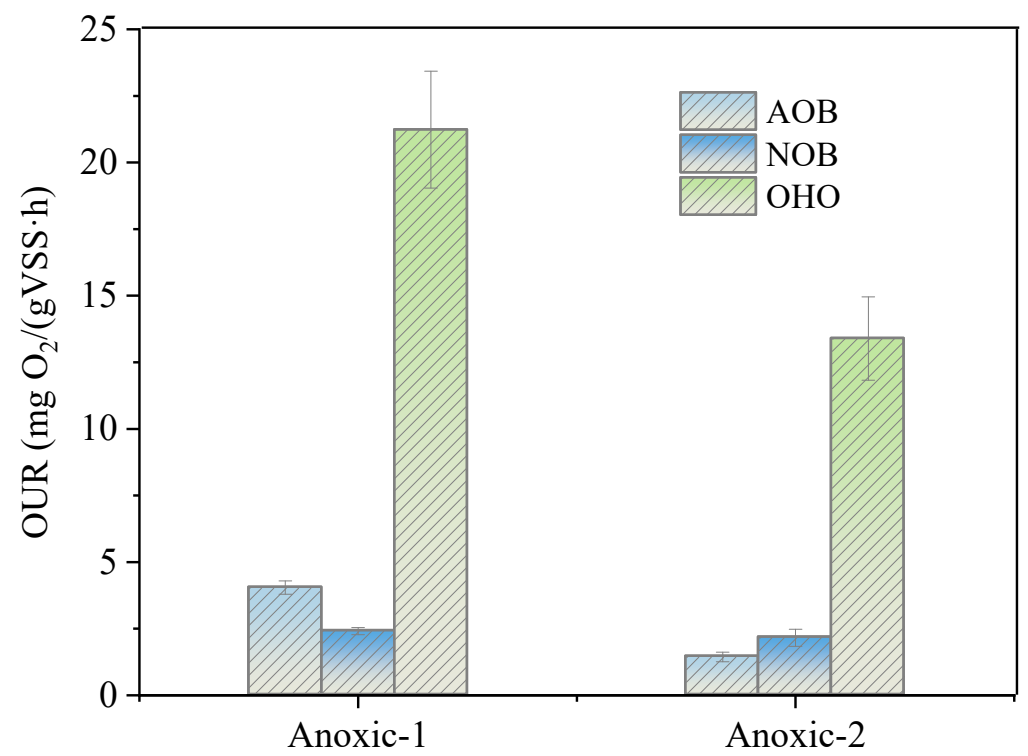

Figure 5. Oxygen uptake rates of $\mathrm{AOB}, \mathrm{NOB}$, and $\mathrm{OHO}$ in the biomass taken from anoxic biofilms.

Furthermore, the ex-situ activities of PD/A were detected in the anoxic biofilm after 147 days of operation. Results showed that the $\mathrm{NO}_{3}{ }^{-}-\mathrm{N}$ concentration decreased rapidly at the beginning of the reaction, along with the increased $\mathrm{NO}_{2}{ }^{-} \mathrm{N}$ (data not shown). Anammox occurred after $30 \mathrm{~min}$ when higher $\mathrm{NO}_{2}{ }^{-}-\mathrm{N}$ was accumulated. The carbon source from the actual domestic wastewater provided sufficient electron donor during the first $30 \mathrm{~min}$, resulting in faster denitrification activity and the accumulation of $\mathrm{NO}_{2}{ }^{-} \mathrm{N}$. At the same time, higher activity of anammox was observed with the simultaneous decrease of $\mathrm{NH}_{4}{ }^{+}-\mathrm{N}, \mathrm{NO}_{2}{ }^{-}-\mathrm{N}$, and $\mathrm{NO}_{3}{ }^{-}-\mathrm{N}$ concentration. This suggested that the organic matter 
concentration in domestic wastewater played an important role in anammox performance in this system, which was consistent with previous studies [42,43]. In this case, it should be taken into consideration that the excess COD concentration has a negative effect on anammox activity and efficient strategies were needed to optimize the carbon utilization by heterotrophic bacteria in practical application.

It can be seen that $\mathrm{NH}_{4}{ }^{+}-\mathrm{N}$ appeared to decrease at the beginning of the second anoxic zone. Since there was much more carbon source than usual in the reactor, the accumulation of $\mathrm{NO}_{2}{ }^{-}-\mathrm{N}$ was also observed in the experiment, and the anammox activity was lower than the denitrification activity at the beginning. The anammox activity in the second anoxic zone was higher than that in the first zone, which could be attributed to the decreasing denitrification activity due to less organic carbon source in the second compartment.

\subsection{COD Removal during Stable Operation}

The COD removal was improved after the addition of anammox sludge. As a result, the effluent COD was kept at $<50 \mathrm{mg} / \mathrm{L}$, with a removal rate of $>75 \%$. The average influent COD was around $172 \mathrm{mg} / \mathrm{L}$, which dropped to $50-60 \mathrm{mg} / \mathrm{L}$ at the end of anoxic zones. This could be due to the dilution by recycling effluent; the COD concentration in the final effluent decreased to $35-45 \mathrm{mg} / \mathrm{L}$.

On the other hand, there was no external COD addition during the whole operation. This was mainly attributed to the denitrification coupling with anammox in anoxic zones in the reactor, which saves the electron donor for complete reduction of $\mathrm{NO}_{3}{ }^{-} \mathrm{N}^{-}$to $\mathrm{N}_{2}$. As for the treatment of wastewater with low $\mathrm{C} / \mathrm{N}$, insufficient carbon sources would limit the denitrification efficiency, resulting in insufficient effluent quality. In this study, more efficient use of carbon sources could be achieved in the anoxic stage for partial reduction of $\mathrm{NO}_{3}{ }^{-}-\mathrm{N}$ to $\mathrm{NO}_{2}{ }^{-}-\mathrm{N}$, which was consumed by anammox bacteria as electron donor. Therefore, desirable TN removal performance could be achieved despite influent $\mathrm{C} / \mathrm{N}$ as low as 2.65. Furthermore, the aeration energy could also be saved due to the $\mathrm{NH}_{4}{ }^{+}-\mathrm{N}$ removal via the anammox pathway in anoxic zones, thus the $\mathrm{NH}_{4}{ }^{+}-\mathrm{N}$ flowing to the aerobic zone would decrease.

\subsection{Effect of DO on Nitrogen Removal of A/O Biofilm System}

In the anoxic zones of the $\mathrm{A} / \mathrm{O}$ biofilm reactor, denitrification and anammox was responsible for the $\mathrm{NO}_{3}{ }^{-}-\mathrm{N}$ and $\mathrm{NH}_{4}{ }^{+}-\mathrm{N}$ removal in the anoxic zone, and complete nitrification for $\mathrm{NH}_{4}{ }^{+}-\mathrm{N}$ oxidation to $\mathrm{NO}_{3}{ }^{-}-\mathrm{N}$ was carried out by AOB and NOB in the aerobic zones. The $\mathrm{NO}_{3}{ }^{-}-\mathrm{N}$ remaining at the end of the anoxic zones would affect directly the TN concentration in the final effluent. Elevated $\mathrm{NO}_{3}{ }^{-}-\mathrm{N}$ concentration at the end of anoxic zones was $0-7 \mathrm{mg} / \mathrm{L}$ during phases I and II, indicating that the reaction in the anoxic zones was not optimal. The biomass in the aerobic zones in a biofilm reactor was less than that of activated sludge, possibly resulting in a high effluent DO level. It should be noted that part of the organic matter would be consumed by $\mathrm{OHO}$ under aerobic conditions rather than for $\mathrm{NO}_{3}{ }^{-}-\mathrm{N}$ reduction in anoxic zones, if a certain amount of $\mathrm{DO}$ was introduced into the anoxic zones from the cycling effluent. In this study, DO concentration in recycling effluent ranged from 4 to $8 \mathrm{mg} / \mathrm{L}$. However, the DO of the first two anoxic zones always remained below $0.1 \mathrm{mg} / \mathrm{L}$. As a result, fewer electron donor could serve for denitrification, resulting in lower TN removal before the PD/A development.

The negative effect of DO on denitrification in anoxic conditions could be alleviated in the stable operation of the PD/A biofilm system. As observed from Figure 3a, there was a difference between the theoretical concentration and the measured value of $\mathrm{NH}_{4}{ }^{+}-\mathrm{N}$ concentration after mixing the recycling effluent with influent wastewater. This indicated that the nitrogen removal in the anoxic stage could be significantly improved by introducing the anammox process. However, a high DO should be avoided since it had a negative effect on anammox activity. The average contribution of the anammox pathway to TN removal achieved $38 \%$ in the stable operation. This was comparable with a previous study, which found that the anammox could account for $32-47 \%$ of TN removal in a step-feed 
AO system [41]. However, this was lower than that in two-stage nitrification and PD/A SBRs treating domestic wastewater, in which the anammox could account for $72 \%$ of TN removal [13]. This was possibly due to the negative effect of DO being much less in a separated reactor for PD/A. Further optimization is needed to improve the anammox contribution in the continuous-flow systems.

These results indicated that enhanced nitrogen removal from low-carbon wastewater could be achieved by PD/A in a continuous-flow biofilm system without the addition of an external organic carbon source. Moreover, the aeration energy could be significantly saved by up to $19 \%$ compared to the traditional nitrification and denitrification process, attributed to $38 \%$ of TN removal by the PD/A process. According to the previous study, the PD/Abased process in theory has the potential for reducing oxygen and organic carbon demands by $50 \%$ and $80 \%$ [13]. Therefore, it is a promising and effective alternative in a continuousflow biofilm reactor to promote anammox contribution and reduce energy consumption. On the other hand, we investigated the $\mathrm{N}_{2} \mathrm{O}$ production in the PD process with high $\mathrm{NO}_{2}{ }^{-}$ $\mathrm{N}$ accumulation in a previous study, which indicated very limited $\mathrm{N}_{2} \mathrm{O}$ production during the reduction from $\mathrm{NO}_{3}{ }^{-}-\mathrm{N}$ to $\mathrm{NO}_{2}{ }^{-}-\mathrm{N}$ process [10]. This was explicable since the $\mathrm{NO}_{3}{ }^{-}-\mathrm{N}$ was converted to $\mathrm{NO}_{2}{ }^{-}-\mathrm{N}$ without further reduction. Additionally, the $\mathrm{N}_{2} \mathrm{O}$ production in the PD/A process under mainstream conditions was explored in our previous study, which illustrated that the maximum $\mathrm{N}_{2} \mathrm{O}$ accumulation in the PD/A process could be as little as $0.7 \%$ of influent nitrogen and was much lower than that previously reported for conventional nitrification-denitrification or single-stage PN/A, and such a small amount of $\mathrm{N}_{2} \mathrm{O}$ could be depleted during the following reaction [13]. This clearly suggested that the $\mathrm{N}_{2} \mathrm{O}$ emission could be mitigated in this process. It was mainly attributed to the transition step from $\mathrm{NO}_{3}{ }^{-}-\mathrm{N}$ to $\mathrm{NO}_{2}{ }^{-}-\mathrm{N}$, followed by $\mathrm{NH}_{4}{ }^{+}-\mathrm{N}$ oxidation via anammox that produced little $\mathrm{N}_{2} \mathrm{O}$ due to the microbial metabolism. Further investigation is necessary to explore the potential risk of $\mathrm{N}_{2} \mathrm{O}$ production in the whole process of the continuous-flow PD/A biofilm system.

\subsection{Abundance of Functional Bacteria in PD/A Biofilm}

The abundance of functional bacteria including AOB, NOB, and anammox bacteria were analyzed by qPCR. In addition, the functional bacteria in suspended biomass returned to anoxic zones by recycling biomass were also investigated.

Results showed that anammox bacteria were enriched in the anoxic biofilms with abundance of $8.69 \times 10^{8}$ and $8.82 \times 10^{8}$ copies $/ \mathrm{gSS}$ in the biofilms of the first and second anoxic zone, accounting for $5.83 \%$ and $4.41 \%$ of total bacteria, respectively (Figure 6). In comparison, it was relatively lower for AOB and two types of NOB in the same biofilms. The abundance of AOB was $1.34 \times 10^{5}$ and $3.15 \times 10^{5}$ copies/gSS. A higher abundance of Nitrospira was detected: $6.46 \times 10^{6}$ and $9.16 \times 10^{6}$ copies/gSS, respectively. The abundance of Nitrobacter was slightly lower, $1.41 \times 10^{6}$ and $2.17 \times 10^{6}$ copies/gSS, respectively. In addition, the abundance of $\mathrm{AOB}$ and $\mathrm{NOB}$ was still low in recycling biomass, indicating that the nitrification by nitrifying bacteria returned from the aerobic zone to the anoxic zone would be very limited. This confirmed that the partial denitrification coupling with anammox was the dominant contributor to $\mathrm{NH}_{4}{ }^{+}-\mathrm{N}$ loss rather than the simultaneous nitrification and denitrification process. The anammox bacteria in recycling biomass would derive from the flocs growth or the fall-off biofilms. Overall, results in this study demonstrated that the anammox bacteria could be retained in the anoxic biofilm community by utilizing $\mathrm{NH}_{4}{ }^{+}-\mathrm{N}$ from domestic wastewater and $\mathrm{NO}_{2}{ }^{-}-\mathrm{N}$ from $\mathrm{NO}_{3}{ }^{-}-\mathrm{N}$ reduction via the PD approach. 


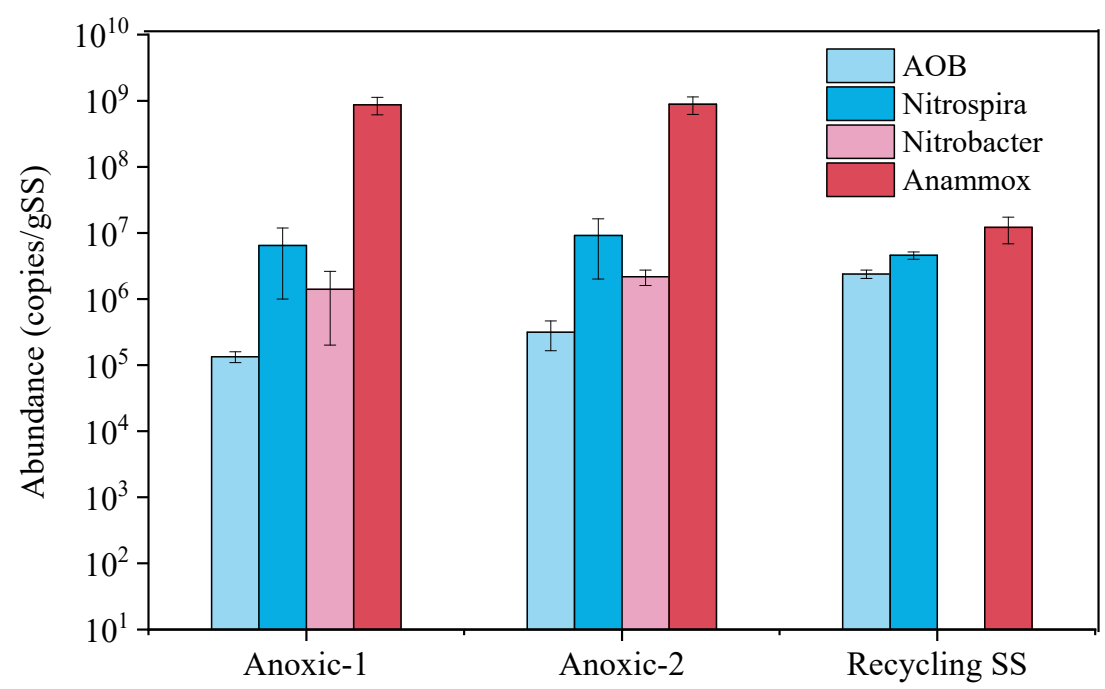

Figure 6. Abundance of nitrifying and anammox bacteria in biofilms.

\section{Conclusions}

This study proposed and demonstrated a novel PD/A biofilm system in a continuousflow reactor for low-carbon domestic wastewater treatment. Satisfactory $\mathrm{NH}_{4}{ }^{+}-\mathrm{N}$ oxidation efficiency above $95 \%$ was achieved due to the rapid biofilm formation in the aerobic zone. High $\mathrm{NO}_{2}{ }^{-}-\mathrm{N}$ accumulation occurred in anoxic zones due to the insufficient organic carbon for complete denitrification, with a peak $\mathrm{NO}_{2}{ }^{-}-\mathrm{N}$ value of $6.0 \mathrm{mg} / \mathrm{L}$ and $\mathrm{NTR}_{\text {an }}$ achieving $64.4 \%$. The TN removal was significantly improved from $37.3 \%$ to $78.0 \%$ despite a low $\mathrm{COD} / \mathrm{TN}$ of 2.65 when anammox sludge was added to the anoxic zones. A high level of anammox contribution of $38 \%$ to TN removal was achieved in the PD/A system. Anammox bacteria could be efficiently retained in the anoxic biofilm and played a key role in advanced nitrogen removal from the domestic wastewater without external organic carbon addition.

Author Contributions: Y.H.: conceptualization, data curation, writing-original draft; Y.P.: supervision, writing - review and editing; D.H.: investigation; J.F.: formal analysis; R.D.: formal analysis, funding acquisition, investigation, writing-review and editing. All authors have read and agreed to the published version of the manuscript.

Funding: This research was funded by National Natural Science Foundation of China (22006003), Beijing Natural Science Foundation (8204056), and the scientific research program of Beijing Municipal Commission of Education (KM202010005011). And The APC was funded by National Natural Science Foundation of China (22006003).

Institutional Review Board Statement: Not applicable.

Informed Consent Statement: Not applicable.

Conflicts of Interest: The authors declare no conflict of interest.

\section{References}

1. Deng, L.; Peng, Y.; Li, J.; Gao, R.; Li, W.; Du, R. Enhanced simultaneous nitrogen and phosphorus removal from low COD/TIN domestic wastewater through nitritation-denitritation coupling improved anammox process with an optimal Anaerobic/Oxic/Anoxic strategy. Bioresour. Technol. 2021, 322, 124526. [CrossRef] [PubMed]

2. Keerio, H.A.; Bae, W.; Park, J.; Kim, M. Substrate uptake, loss, and reserve in ammonia-oxidizing bacteria (AOB) under different substrate availabilities. Process Biochem. 2020, 91, 303-310. [CrossRef]

3. Ji, B. Towards environment-sustainable wastewater treatment and reclamation by the non-aerated microalgal-bacterial granular sludge process: Recent advances and future directions. Sci. Total Environ. 2022, 806, 150707. [CrossRef]

4. Zhu, G.; Wang, S.; Feng, X.; Fan, G.; Jetten, M.S.M.; Yin, C. Anammox Bacterial Abundance, Biodiversity and Activity in a Constructed Wetland. Environ. Sci. Technol. 2011, 45, 9951-9958. [CrossRef] [PubMed]

5. Cao, S.; Yan, W.; Yu, L.; Zhang, L.; Lay, W.; Zhou, Y. Challenges of THP-AD centrate treatment using partial nitritation-anammox (PN/A) - Inhibition, biomass washout, low alkalinity, recalcitrant and more. Water Res. 2021, 203, 117555. [CrossRef] [PubMed] 
6. Miao, Y.; Liang, Z.; Yang, Y.; Peng, Y.; Li, B.; Wang, S.; Qian, Z. Start-up of single-stage partial nitrification-anammox process treating low-strength swage and its restoration from nitrate accumulation. Bioresour. Technol. 2016, 218, 771-779. [CrossRef] [PubMed]

7. Miao, Y.; Zhang, L.; Yu, D.; Zhang, J.; Zhang, W.; Ma, G.; Zhao, X.; Peng, Y. Application of intermittent aeration in nitrogen removal process: Development, advantages and mechanisms. Chem. Eng. J. 2021, 430, 133184. [CrossRef]

8. Cao, S.; Zhou, Y. New direction in biological nitrogen removal from industrial nitrate wastewater via anammox. Appl. Microbiol. Biotechnol. 2019, 109, 7459-7466. [CrossRef]

9. Cao, S.; Wang, S.; Peng, Y.; Wu, C.; Du, R.; Gong, L.; Ma, B. Achieving partial denitrification with sludge fermentation liquid as carbon source: The effect of seeding sludge. Bioresour. Technol. 2013, 149, 570-574. [CrossRef]

10. Du, R.; Peng, Y.; Cao, S.; Wang, S.; Niu, M. Characteristic of nitrous oxide production in partial denitrification process with high nitrite accumulation. Bioresour. Technol. 2016, 203, 341-347. [CrossRef]

11. Cao, S.; Du, R.; Meng, N.; Li, B.; Ren, N.; Peng, Y. Integrated anaerobic ammonium oxidization with partial denitrification process for advanced nitrogen removal from high-strength wastewater. Bioresour. Technol. 2016, 221, 37. [CrossRef] [PubMed]

12. Du, R.; Peng, Y.; Ji, J.; Shi, L.; Gao, R.; Li, X. Partial denitrification providing nitrite: Opportunities of extending application for anammox. Environ. Int. 2019, 131, 105001. [CrossRef]

13. Du, R.; Cao, S.; Zhang, H.; Li, X.; Peng, Y. Flexible Nitrite Supply Alternative for Mainstream Anammox: Advances in Enhancing Process Stability. Environ. Sci. Technol. 2020, 54, 6353-6364. [CrossRef] [PubMed]

14. Du, R.; Peng, Y.; Cao, S.; Wang, S.; Wu, C. Advanced nitrogen removal from wastewater by combining anammox with partial denitrification. Bioresour. Technol. 2015, 179, 497-504. [CrossRef]

15. Ge, H.; Batstone, D.; Keller, J. Evaluation of anaerobic digestion processes for short sludge-age waste activated sludge combined with anammox treatment of digestate liquor. Water Sci. Technol. 2016, 73, 1052-1060. [CrossRef]

16. Winkler, M.K.; Yang, J.; Kleerebezem, R.; Plaza, E.; Trela, J.; Hultman, B.; van Loosdrecht, M.C. Nitrate reduction by organotrophic Anammox bacteria in a nitritation/anammox granular sludge and a moving bed biofilm reactor. Bioresour. Technol. 2012, 114, 217. [CrossRef]

17. Zhang, J.; Peng, Y.; Li, X.; Du, R. Feasibility of partial-denitrification/ anammox for pharmaceutical wastewater treatment in a hybrid biofilm reactor. Water Res. 2022, 208, 117856. [CrossRef]

18. Malovanyy, A.; Yang, J.; Trela, J.; Plaza, E. Combination of upflow anaerobic sludge blanket (UASB) reactor and partial nitritation/anammox moving bed biofilm reactor (MBBR) for municipal wastewater treatment. Bioresour. Technol. 2015, 180, 144-153. [CrossRef] [PubMed]

19. Wells, G.F.; Shi, Y.; Laureni, M.; Rosenthal, A.; Szivák, I.; Weissbrodt, D.G.; Joss, A.; Buergmann, H.; Johnson, D.R.; Morgenroth, E. Comparing Resistance, Resilience, and Stability of Replicate Moving Bed Biofilm and Suspended Growth Combined NitritationAnammox Reactors. Environ. Sci. Technol. 2017, 51, 5108. [CrossRef]

20. Ferrai, M.; Guglielmi, G.; Andreottola, G. Modelling respirometric tests for the assessment of kinetic and stoichiometric parameters on MBBR biofilm for municipal wastewater treatment. Environ. Modell. Softw. 2010, 25, 626-632. [CrossRef]

21. Xiao, G.Y.; Ganczarczyk, J. Structural features of biomass in a hybrid MBBR reactor. Environ. Technol. 2006, 27, 289-298. [CrossRef]

22. Hedegärd, M.; Wik, T. An online method for estimation of degradable substrate and biomass in an aerated activated sludge process. Water Res. 2011, 45, 6308-6320. [CrossRef] [PubMed]

23. Nogueira, R.; Melo, L.F.; Purkhold, U.; Wuertz, S.; Wagner, M. Nitrifying and heterotrophic population dynamics in biofilm reactors: Effects of hydraulic retention time and the presence of organic carbon. Water Res. 2002, 36, 469-481. [CrossRef]

24. Chen, Z.; Qiu, S.; Yu, Z.; Li, M.; Ge, S. Enhanced Secretions of Algal Cell-Adhesion Molecules and Metal Ion-Binding Exoproteins Promote Self-Flocculation of Chlorella sp. Cultivated in Municipal Wastewater. Environ. Sci. Technol. 2021, 55, 11916-11924. [CrossRef] [PubMed]

25. Zhu, G.; Wang, S.; Wang, W.; Wang, Y.; Zhou, L.; Jiang, B.; Op den Camp, H.J.M.; Risgaard-Petersen, N.; Schwark, L.; Peng, Y.; et al. Hotspots of anaerobic ammonium oxidation at land-freshwater interfaces. Nat. Geosci. 2013, 6, 103-107. [CrossRef]

26. Deng, Y.; Zhang, X.; Miao, Y.; Hu, B. Exploration of rapid start-up of the CANON process from activated sludge inoculum in a sequencing biofilm batch reactor (SBBR). Water Sci. Technol. 2016, 73, 535. [CrossRef]

27. Andriy, M.; Jozef, T.; Elzbieta, P. Mainstream wastewater treatment in integrated fixed film activated sludge (IFAS) reactor by partial nitritation/anammox process. Bioresour. Technol. 2015, 198, 478-487.

28. Ma, B.; Qian, W.; Yuan, C.; Yuan, Z.; Peng, Y. Achieving mainstream nitrogen removal through coupling anammox with denitratation. Environ. Sci. Technol. 2017, 51, 8405-8413. [CrossRef]

29. Gao, R.; Peng, Y.; Li, J.; Liu, Y.; Deng, L.; Li, W.; Kao, C. Mainstream partial denitrification-anammox (PD/A) for municipal sewage treatment from moderate to low temperature: Reactor performance and bacterial structure. Sci. Total Environ. 2022, 806, 150267. [CrossRef]

30. Zhao, W.; Huang, Y.; Wang, M.; Pan, C.; Li, X.; Peng, Y.; Li, B. Post-endogenous denitrification and phosphorus removal in an alternating anaerobic/oxic/anoxic (AOA) system treating low carbon/nitrogen $(\mathrm{C} / \mathrm{N})$ domestic wastewater. Chem. Eng. J. 2018, 339, 450-458. [CrossRef]

31. Tsuneda, S.; Park, S.; Hayashi, H.; Jung, J.; Hirata, A. Enhancement of nitrifying biofilm formation using selected EPS produced by heterotrophic bacteria. Water Sci. Technol. 2001, 43, 197-204. [CrossRef] 
32. Du, R.; Cao, S.; Wang, S.; Niu, M.; Peng, Y. Performance of partial denitrification (PD)-ANAMMOX process in simultaneously treating nitrate and low C/N domestic wastewater at low temperature. Bioresour. Technol. 2016, 219, 420. [CrossRef] [PubMed]

33. Alves, C.F.; Melo, L.F.; Vieira, M.J. Influence of medium composition on the characteristics of a denitrifying biofilm formed by Alcaligenes denitrificans in a fluidised bed reactor. Process Biochem. 2002, 37, 837-845. [CrossRef]

34. Zhang, L.; Zhang, S.; Peng, Y.; Han, X.; Gan, Y. Nitrogen removal performance and microbial distribution in pilot- and full-scale integrated fixed-biofilm activated sludge reactors based on nitritation-anammox process. Bioresour. Technol. 2015, 196, 448-453. [CrossRef] [PubMed]

35. APHA. Standard Methods for the Examinations of Water and Wastewater. In American Water Works Association and Water Environment Federation, 21st ed.; American Public Health Association: Washington, DC, USA, 2005.

36. Lima, P.S.; Inacio, A.T.; Moreira, Y.C.; César, D.E.; Dias, R.J.P.; Dezotti, M.; Bassin, J.P. Upgrade of a suspended biomass reactor with limited nitrification to a biofilm system: Addressing critical parameters and performance in different reactor configurations. Biochem. Eng. J. 2021, 170, 107987. [CrossRef]

37. Ge, S.; Peng, Y.; Wang, S.; Lu, C.; Cao, X.; Zhu, Y. Nitrite accumulation under constant temperature in anoxic denitrification process: The effects of carbon sources and COD/ $\mathrm{NO}_{3}{ }^{-}-\mathrm{N}$. Bioresour. Technol. 2012, 114, 137-143. [CrossRef]

38. Shi, L.; Du, R.; Peng, Y. Achieving partial denitrification using carbon sources in domestic wastewater with waste-activated sludge as inoculum. Bioresour. Technol. 2019, 283, 18-27. [CrossRef]

39. Du, R.; Cao, S.; Niu, M.; Li, B.; Wang, S.; Peng, Y. Performance of partial-denitrification process providing nitrite for anammox in sequencing batch reactor (SBR) and upflow sludge blanket (USB) reactor. Int. Biodeter. Biodegr. 2017, 122, 38-46. [CrossRef]

40. Gao, R.; Peng, Y.; Li, J.; Du, R.; Yang, L.; Wang, M.; Deng, L. Nitrogen removal from low COD/TIN real municipal sewage by coupling partial denitrification with anammox in mainstream. Chem. Eng. J. 2021, 410, 128221. [CrossRef]

41. Li, J.; Peng, Y.; Zhang, L.; Liu, J.; Wang, X.; Gao, R.; Pang, L.; Zhou, Y. Quantify the contribution of anammox for enhanced nitrogen removal through metagenomic analysis and mass balance in an anoxic moving bed biofilm reactor. Water Res. 2019, 160, 178-187. [CrossRef]

42. Ni, S.Q.; Ni, J.Y.; Hu, D.L.; Sung, S. Effect of organic matter on the performance of granular anammox process. Bioresour. Technol. 2012, 110, 701. [CrossRef] [PubMed]

43. Du, R.; Cao, S.; Li, B.; Niu, M.; Wang, S.; Peng, Y. Performance and microbial community analysis of a novel DEAMOX based on partial-denitrification and anammox treating ammonia and nitrate wastewaters. Water Res. 2017, 108, 46-56. [CrossRef] [PubMed] 